\title{
Coastal Upwelling and Its Teleconnections with Large Scale Indices in a Changing Environment along the Southwest Coast of India
}

\author{
Muni Krishna K1* and Manjunatha B 2 \\ ${ }^{1}$ Department of Meteorology and Oceanography, Andhra University, India \\ ${ }^{2}$ Department of Marine Geology, Mangalore University, India
}

Submission: December 11, 2017; Published: March 15, 2018

*Corresponding author: Muni Krishna K, Department of Meteorology and Oceanography, Andhra University, Visakhapatnam, India, Email: munikrishnna@yahoo.co.in

\begin{abstract}
Coastal upwelling process along the southwest coast of India (SCI) is dominated by the seasonal reversal of winds between the southwest and northeast monsoons. Variations in the coupled ocean-atmospheric system impact upwelling patterns and other climatic elements in SCI. Changes in the upwelling system in turn modify sea surface temperatures, sea level heights, and coastal climate. This study examines upwelling patterns from 1946-2005 along the SCI, and ties these patterns to variations in air-sea interactions. While upwelling is controlled daily mostly by local characteristics of winds, coastal topography and bathymetry, large atmospheric feature such as Pacific Decadal Oscillation, Northern Oscillation Index and El Niño / La Nina events dominate local conditions. Study of monthly sea surface temperature anomaly (SSTA) and Ekman Transport (ET) along the SCI reveals that both SSTA and ET are found to be low and high during the study period and both having significant strong relation (significant at 99.9\% level). Results from this indicate that air-sea interactions on a large-scale do explain trends and variability of upwelling along the SCI. Additionally, these findings also point to the possible influences of global warming. Furthermore, local climatic records reveal the influence of coastal atmospheric/oceanic variations on SCI climate.
\end{abstract}

Keywords: Sea surface temperature; Along shore wind; Ekman transport; PDO; NOI

\section{Introduction}

Sea surface temperature and the nutrient content produced by coastal upwelling are among the most important large scale variables influencing the marine environment. Previous studies to quantify the influence of climate change on coastal upwelling [1] used climate models with much simpler representations of the ocean than are common today. A number of recent papers have explored the patterns and dynamics of fluctuations embedded within the long-term, globally integrated tendency commonly referred to as climate change [2-6]. However, these studies have concentrated on large-scale temporal oscillations, generally on decadal scales; fewer examples describe variability on subbasin (i.e., $100-1000 \mathrm{~km}$ ) space scales. In a particular striking example of how global climate change may be affecting ocean conditions on smaller scales, Bakun [7] postulate that under the scenario of global warming, continental air mass will warm more rapidly than oceanic air masses, leading to an intensified summer continental atmosphere low, a greater cross-margin pressure gradient between the continental low and higher pressure over the cooler ocean, stronger equator ward wind stress, and increased coastal upwelling along eastern ocean boundaries. The effect on eastern boundary current systems could be significant because of the highly productive nature of these ecosystems and their potentially important role in the global $\mathrm{CO} 2$ budget.

Upwelling is not a temporally continuous or spatially uniform process, but the period of upwelling and favorable conditions (as well as substantial interannual variability) and has a distribution that suggests certain regions or sites are more conducive to upwelling [8]. Empirical studies of upwelling and its effects on biological production suggest that optimal fisheries production in eastern boundary currents occurs within a limited range of wind speeds; at speeds greater than about $5-7 \mathrm{~m} / \mathrm{s}$ the biomass of small pelagic fish decreases [9]. This has resulted in ecosystems that are tuned to these variations. Any long-term changes in the seasonal patterns of upwelling, their intensity or the duration of upwelling events could have dramatic implications to their living marine resources. Because upwelling has a very complex and regionalized spatial structure, its character cannot be determined or quantified with spatially integrated indices (e.g., globally or ocean-averaged sea surface temperature (SST) time series), or with a single index from an isolated location. Any long-term changes in the seasonal patterns of upwelling, their intensity or the duration of upwelling events could have 
dramatic implications to their living marine resources. Large scale ocean-atmospheric changes related to annual occurrences of ENSO events and decadal shifts associated with the pacific decadal oscillation (PDO) and Northern oscillation index (NOI) impact sea surface temperature anomaly (SSTA).

Marine ecosystems are currently exposed to two problemic global trends:

a. The incessant accumulation of global gases in the earth's atmosphere, raising the threat of major changes associated with global warming and also of inevitable rearrangements of the established patterns of energy and momentum transfers through the sea surface that control processes that have become ingrained in marine life-history strategies, and

b. Heavy industrial fishery exploitation that has become pandemic in the world's oceans.

Bakun [7] opens the disquieting possibility that as incessant accumulation of global gases in the earth's atmosphere continues, additional intense regional upwelling ecosystems that exist in other regions of the world's ocean might be switched to undesirable states similar to the currently existing off Luderitz. One of the reasons that coastal upwelling tends to be a more year-round phenomena in the tropics, is that a strong pressure gradient forms between a thermal low pressure cell that develops over the heated land surface an higher pressure existing over the more slowly warming waters of the ocean. This crossshore pressure gradient supports an alongshore geostrophic wind that drives and offshore-directed Ekman transport of the ocean surface layer. When the surface waters are thereby forced offshore from the solid coastal boundary on spatial scales too large for them to be replaced by waters moving horizontally along the coast, mass balanced is maintained by upwelling of subsurface waters. As atmospheric global content increases, the rate of heating over the land is further enhanced relative to that over the ocean, particularly as night-time radiative cooling is suppressed by an increasing degree of blockage of outgoing longwave radiation. This causes intensification of the low pressure cells over the coastal interior. A feedback sequence is generated as the resulting pressure gradient increase is matched by a proportional wind increase, which correspondingly increase the intensity of the upwelling in a non linear manner (by a power of 2 or more these strong wind conditions) which, in concert with ocean surface cooling produced by the intensified upwelling, further enhances the land-sea temperature contrast, the associated cross-shore pressure gradient, the upwelling favorable win, and so on [10-15].

The southwest coast of India is a monsoon dominated coast. Coastal upwelling occurs along the coast during the southwest monsoon season (JJAS) between $7^{\circ} \mathrm{N}$ and $15^{\circ} \mathrm{N}$ [16-21]. In this region, upwelling is a wind-driven process and the strength of alongshore winds stress modulates the coastal divergence and hence the input of cold upwelled water over the shelf. A strengthening of the alongshore wind stress enhances upwelling and results in lower SST over the shelf. Upwelling trends and patterns at three coastal locations for the past 60 years are examined and related local winds, sea level heights, SSTs and Pacific climatic indices to establish trends and mechanisms responsible for changes observed. Possible ties of upwelling to global warming and climate change are also investigated and speculation of their future impacts on southwest coast of India upwelling presented. Finally, coastal variability is relate to changes in southwest coast climate and speculate how trends will impact future climate variability.

\section{Data and Methods}

The wind speed data (calculated by assuming a constant wind stress drag coefficient $\mathrm{Cd}=1.5 \times 10^{-3}$ ) and SST data were taken from Comprehensive Ocean-Atmosphere Data Set (COADS), a monthly averaged, $2^{\circ} \times 2^{\circ}$ resolution, historical data file of ocean observations starting from 1899. The data have been collected, quality controlled and put into common formats and units [22-25]. As the data density before 1946 was poor and the measurement procedure has changed since 1946, only data from 1946 to 2005 were used in this study. The geographical boxes are referred to in terms of their central latitude (e.g., $8{ }^{\circ} \mathrm{N}$ refers to the $7^{\circ}-9^{\circ} \mathrm{N}$ COADS box).

Two large scale indices are used to investigate the atmospheric teleconnections, one is Northern Oscillation Index (NOI), a new index of climate variability based on the difference in 55 sea level pressure (SLP) anomalies at the North Pacific High (NPH) in the northeast Pacific (NEP) and near Darwin, 56 Australia, in a climatologically low SLP region. NOI data is downloaded from http://www.pfeg.noaa.gov/products/PFEL/ modeled/indices/NOIx/noix.html during 1948 to 2005 on monthly basis. Second one is The «Pacific Decadal Oscillation» (PDO) is a long-lived El Niño-like pattern of Pacific climate variability [26]. While the two climate oscillations have similar spatial climate fingerprints, they have very different behavior in time and the data is downloaded from http://jisao.washington. edu/pdo/ during the study period.

Fig I shows the four stations labelled A-D along the southwest coast of India for which the alongshore wind stress have been computed. The wind stress was calculated using a constant drag coefficient of $1.5 \times 10-3$. (Because wind stress is used in this paper as a relative index of upwelling), the choice of the constant drag coefficient is not critical, as a higher drag coefficient will simply linearly scale up our wind stress values. The average orientation of the coastline at each station was measured from maps, and the alongshore wind stress component was then computed. Details are given in Xie \& Hsieh [27]. Ekman transport (ET) was calculated using wind data from ICOADS, W, the sea density, $\rho_{w}=1025 \mathrm{kgm}^{-3}$, a dimensionless drag coefficient $C_{d}=1.5 \times 10^{-3}$, and the air density, , by means of 


\section{Oceanography \& Fisheries Open access Journal}

$$
M_{x}=\left(\frac{\rho_{a} c_{d}}{\rho_{w} f}\right)\left(u^{2}+v^{2}\right)^{\frac{1}{2}} v^{\text {and }} M_{y}=\left(\frac{\rho_{a} c_{d}}{\rho_{w} f}\right)\left(u^{2}+v^{2}\right)^{\frac{1}{2}} u
$$

$\mathrm{f}$ is the coriolis parameter defined as twice the vertical compoentn of the earth's angular velocity, $\Omega$, about the local vertical given by $f=2 \Omega \sin (\theta)$ at latitude $\theta$. Finally $=, \mathrm{x}$ subscript corresponds to the zonal component and the $\mathrm{y}$ subscript to the meridional one [28] (Figure 1).

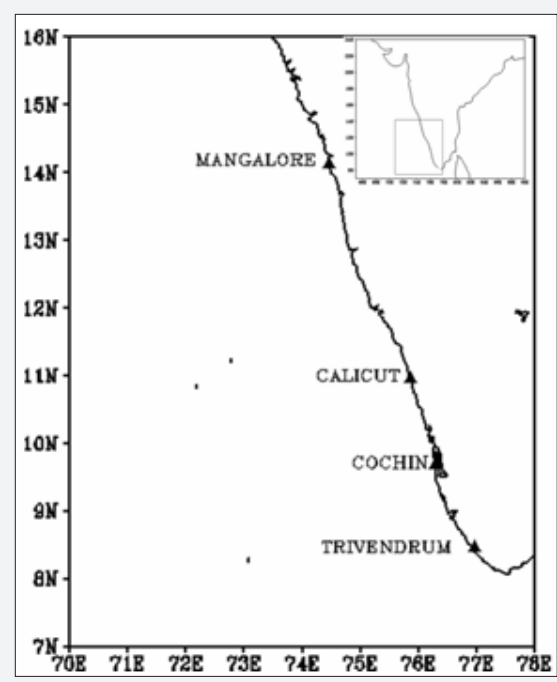

Figure 1: Location map of coastal stations from which monthly time series were generated.
Table 1: Correlation between NOI, PDO and SSTA along the SCI (NOI - 1948-2005, PDO-1946-2005), significant at 99.9\% level.

\begin{tabular}{|c|c|c|}
\hline & NOI & PDO \\
\hline Trivendrum & -0.55 & 0.41 \\
\hline Cochin & -0.55 & 0.4 \\
\hline Calicut & -0.57 & 0.46 \\
\hline Manglore & -0.51 & 0.43 \\
\hline
\end{tabular}

\section{Results}

The mean wind stress for June-September (the upwelling "season") were calculated for each year from the seasonal model series for the COADS $2^{\circ}$ boxes, and plotted as upwelling time series (Figure 2). The alongshore winds stress during the summer season (JJAS) has apparently intensified in the 30-year period 1946 to 1976. Since 1976 the stress values have trended back toward the mean for entire ( $\sim 60$ year) period. Actually, the period since 1976 has been one of anomalously warm conditions in the ocean off the southwest coast of India; whether warm ocean condition could have affected the onshore-offshore pressure gradient by lessening the relative barometric high at the oceanic end of the gradient is unclear. In any case, substantial, natural interannual and inter decadal variability should be super imposed on any trend related to climate warming. Certainly, the trend line fitted to the values in Figure 2 indicates a trend toward substantially increased southward wind stress off the southwest coast of India, even over entire 1946 to 2005 period.

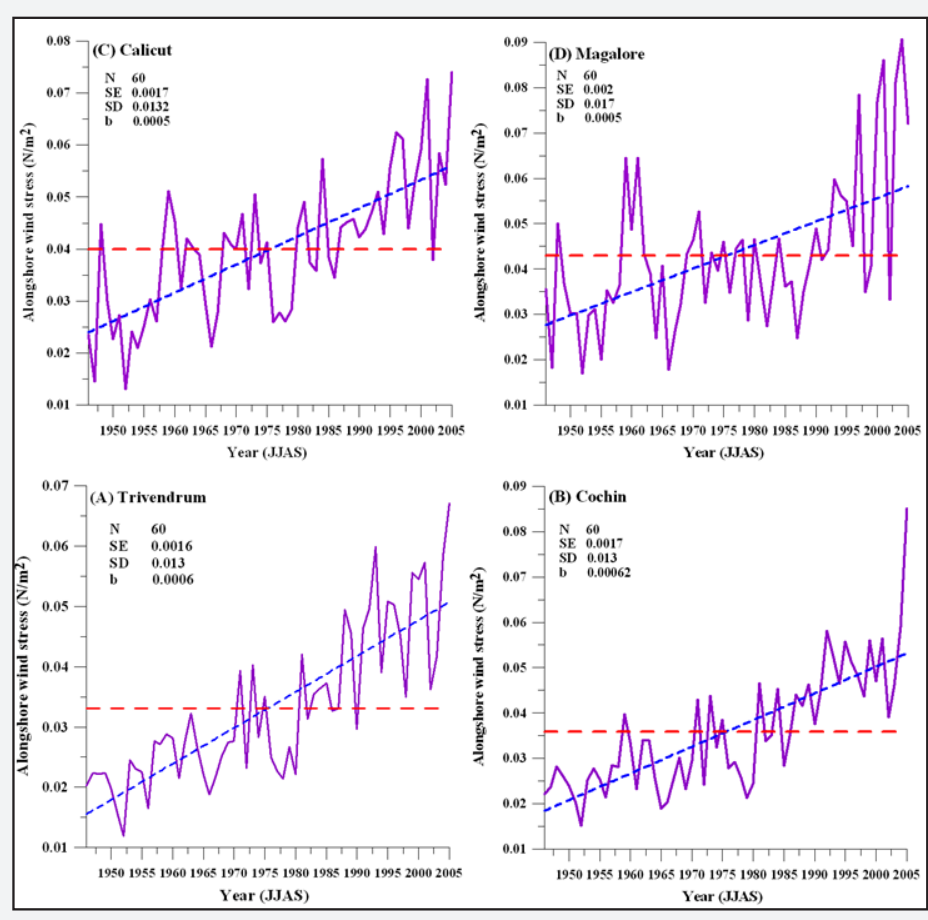

Figure 2 : Within-year averages of monthly estimates of alongshore wind stress off (A) Trivendrum, (B) Cochin, (C) Calicut and (D) Mangalore, Short dashes with blue colour indicates the linear trend fitted by the method of least squres. Longer dashes with red colour indicate the long-term mean of each series. N - Number of points, SE- Standard Error, SD - Standard deviation, b - slope. 
The summer (June - September) alongshore wind stress (Figure 2) shows generally strong upwelling at stations A - D. Comparing the stress from the 1976s onward with earlier wind stress, the upwelling winds have intensified at stations A and B. At the four stations, low stress values are observed during El Niño events. AS shown in Figure 2, the sudden decrease of alongshore wind stress observed in summers of 1952, 1956, 1961, 1966, 1972, 1974, 1978, 1980, 1982, 1987, 1990, 1994, 1998 and 2002 can all be related to El Niño events. During a typical E Nino, this develops in the northern summer, a strong atmospheric teleconnection pattern of alternating high and low pressure cells.
Coastal SSTs during the upwelling season (JJAS) show a shift from the cool phase to the warm phase leading to a warming trend for the period 1946-2005 along the southwest coast of India (Figure 3). The rapid drop in SSTs in 1998, a strong La Nina, corresponds with increased upwelling at stations A and B. After five cool summers in the southwest coast of India, weak El Niño brought warmer waters and reduced upwelling in 200203. Coastal winds stress was unusually weak in 2002 (Figure 2). The relationship between SSTs and upwelling is not simple. Large-scale Southwest coast of India SST patterns influence atmospheric circulation, which in turn drives the coastal current.

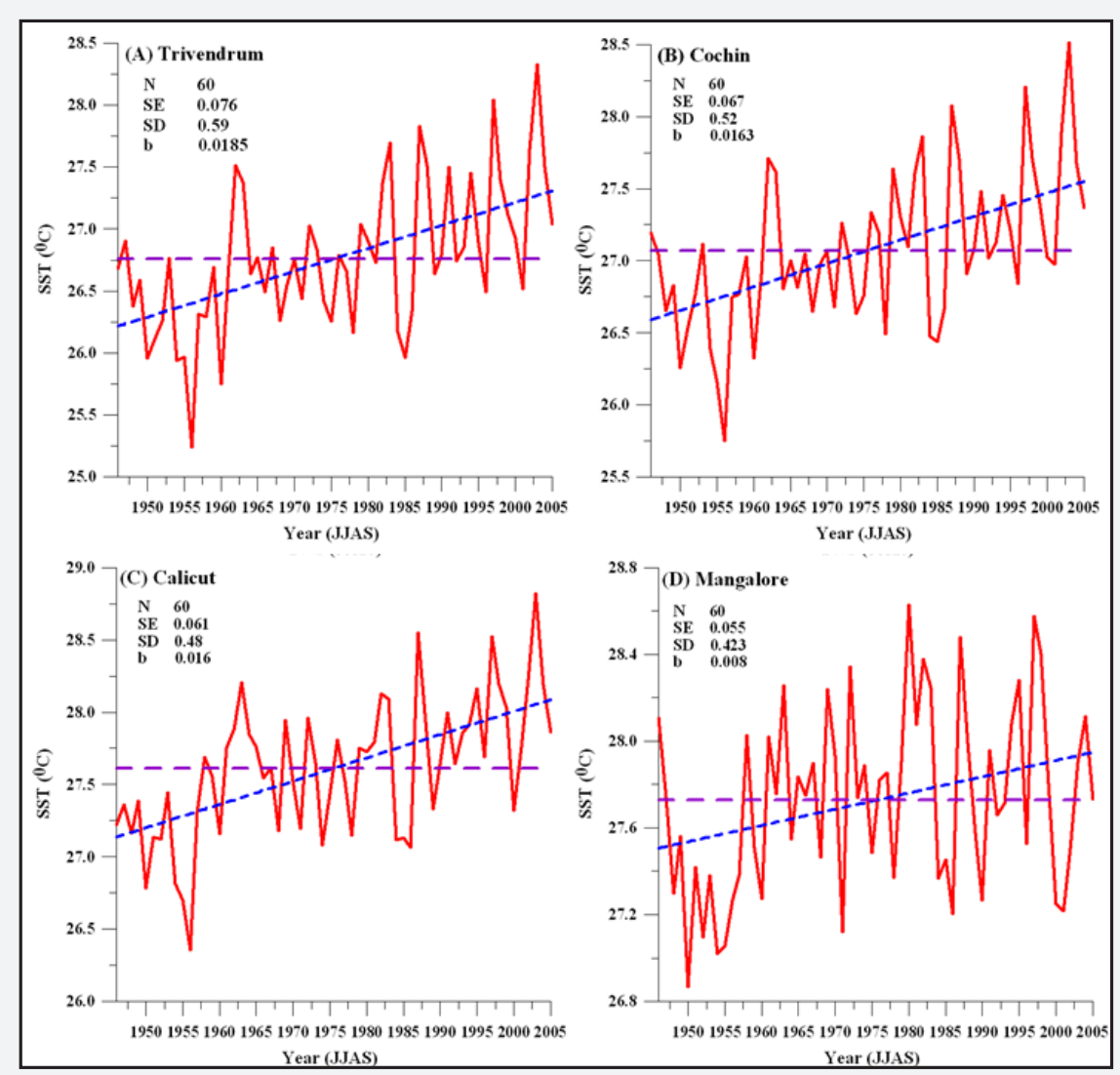

Figure 3 : Within-year averages of monthly sea surface temperature off (A) Trivendrum, (B) Cochin, (C) Calicut and (D) Mangalore, Short dashes with blue colour indicates the linear trend fitted by the method of least squares. Longer dashes with violet colour indicate the longterm mean of each series. N - Number of points, SE- Standard Error, SD - Standard deviation, b - slope.

The existence of SSTA during summer monsoon season (JJAS) at the SCI and significant positive correlation between SSTA and $\mathrm{M}_{\mathrm{y}}$ for southwest monsoon along the SCI (Figure 4) and the relation is statistical significant at $99.9 \%$ level at three locations (Trivendrum, Cochin and Calicut). This relation strongly suggests that the SSTA variations are caused due to coastal upwelling. It is thus clear that the alongshore wind stress is responsible for causing the upwelling along the SCI similar to that of western Arabian Sea. Alongshore winds and coastal upwelling patterns are reflected in the temperature and precipitation patterns along the SCI. The link between the PDO, NOI and upwelling is investigated by looking at the correlation between indices (NOI, PDO) and the corresponding SSTA over the areas represented in Figure 1 (Table 1). Negative and statistically significant at 99.9\% level correlation between NOI and SSTA at four locations along the SCI. Positive and statistically significant at $99.9 \%$ level correlation between PDO and SSTA over the same areas represented in Figure 1. These correlations suggest that an intensification of westerlies across the SCI intensifies the upwelling favourable wind that also enhances the upwelling process (negative SST anomaly). The relationship emphasizes the pre-eminent rate of climate variability on coastal sea surface temperature trends. The observed physical coupling between NOI, PDO and SSTA through an effect of climate on water column stratification. 

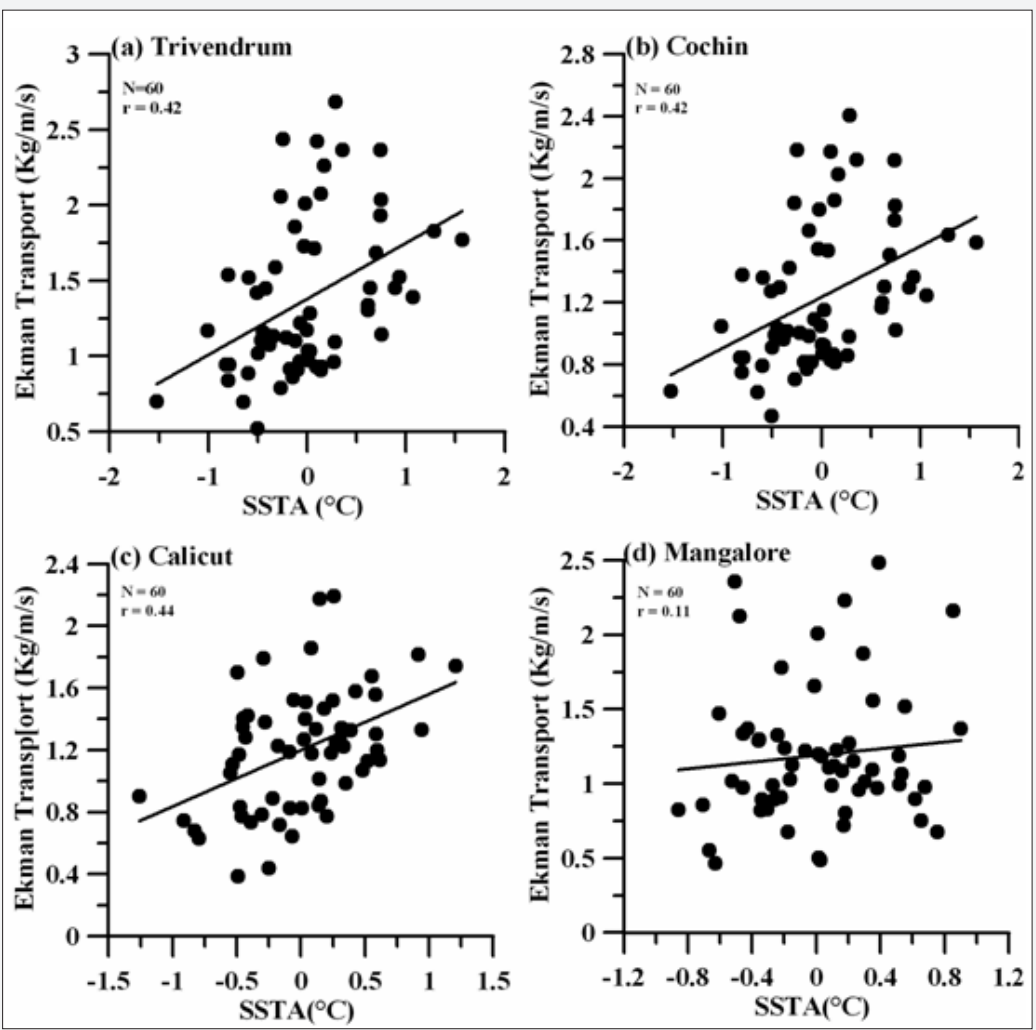

Figure 4 : Correlation between Sea surface temperature anomaly and Ekman Transport along the SCI.

\section{Conclusion}

Alongshore wind stress that drives coastal upwelling has been increasing during the upwelling season (JJAS) of the past 60 years. These are the only seasons during which thermal lows in surface atmospheric pressure develop over the adjacent land mass and therefore in which the hypothesized greenhouse mechanism could operate. When various series are differenced, effectively removing the linear trends, significant interregional correlation among the time series vanishes. Evidently, the only feature shared among regions is the long term trend. Other known types of global teleconnections, such as El Niño-Southern Oscillation, are known to evident in shorter period components of inter-annual variability. The substantial shorter period inter-annual variability is evident in the time series (Figure 2) is apparently not shared among regions to any significant degree. A greenhouse mechanism is consistent with the simple monotonically increasing trend that corresponds to the observed interregional patterns.

Increase upwelling is related to alongshore winds and large scale ocean-atmospheric interactions such as the NOI and PDO. The trends in SSTA, alongshore winds stress follow the gradual warming taking place for the last few decades, they are also explain in terms of large scale switches in phases of the PDO and NOI. The relationship between the SSTA and the ekman transport along the SCI indicates that upwelling occurs due to wind drive systems.
In projecting direct physiological effects of climatic warming on organisms, a first inclination might be to merely increment present characteristic isotherm patterns and to predict changes in biological distributions according to the resulting translocation of temperature ranges. Clearly, there are problems with such a procedure. Also, care must be taken in using evidence from past warming epochs, where various casual aspects of the warming have been some what different, to predict the effects of global warming on the ocean ecosystem. The dynamic ocean processes that determine the SST distributions could be fundamentally altered. Many of the consequences of global climate change to marine ecosystems and also to marine-influenced terrestrial systems could depend on the relative importance, in each local situation, of these competing effects.

\section{Acknowledgment}

I thank Climate Diagnostics Center, NOAA, PFEL and JISAO for providing me the COADS, NOI and PDO data. The present research work is funded by the Department of Science and Technology, Govt. of India under the Fast Track Young Scientist Project (SR/ FTP/ES-09/2008) which is gratefully acknowledged.

\section{References}

1. Hsiesh WW, Boer GJ (1992) Global climate change and ocean upwelling. Fish Oceanogr 1(4): 333-338.

2. Trenberth KE (1990) Recent observed interdecadal climate changes in the northern hemisphere. Bull Am Meteorol Soc 71: 988-993. 
3. Mann ME, Park J (1993) Spatial correlations of inter-decadal variation in global surface temperatures. Geophys Res Lett 20(11): 1055-1058.

4. Mann ME, Park J (1994) Global-scale models of surface temperature variability on interannual to century time scales. J Geophys Res 99(D12): 25819-25833.

5. Mann ME, Park J (1996) Greenhouse warming and the seasonal cycle of temperature: Observations versus model predictions. Geophys Res Lett 23: 1111-1114.

6. Graham NE (1994) Decadal scale variability in the 1970's and 1980's: Observations and model results. Clim Dyn 10(3): 135-162.

7. Bakun A (1990) Global climate change and intensification of coastal upwelling. Science 247(4939): 198-201.

8. Rosenfeld LK., Schwing FB, Garfield N, Tracy DE (1994) Bifurcated flow from an upwelling center: A cold water source for Monterrey Bay. Cont Shelf Res 14: 931-964.

9. Cury P, Roy C (1989) Optimal environmental window and pelagic fish recruitment success in upwelling areas. Can J Fish Aquat Sci 46(4): 670-680.

10. Trenberth KE, Large WG, Olson JG (1990) The mean annual cycle in global ocean wind stress. J Phys Oceanogr 20: 1742-1760.

11. Schwing FB, Mendelssohn R (1997) Increased coastal upwelling in the California current system. J Geophys Res 102(C2): 3421-3438.

12. Bakun A, Roy C, Lluch-Cota S (1998) Coastal upwelling and other processes regulating ecosystem productivity and fish production in the western Indian Ocean, In: Okemwa E, Ntiba M, Sherman K (Eds.), Large Marine Ecosystems of the Indian Ocean Assessment, Sustainability, and Management. Blackwell Science Malden, Massachusetts, USA, pp. 103-141.

13. Mote PW, Mantua NJ (2002) Coastal upwelling in a warmer future. Geophys Res Lett 29(23): 2138-2141.

14. Mendelssohm R, Schwing FB (2002) Common and uncommon trends in SST and wind stress in the California and Peru-Chile current systems. Prog Oceanogr 53: 141-162.

15. Diffenbaugh NS, Snyder MA, Solan LC (2004) Could $\mathrm{CO}_{2}$-induced landcover feedbacks alter near-shore upwelling regimes? Proc Natl Acad Sci USA 101(1): 27-32.
16. Banse K (1959) On upwelling and bottom-trawling off the southwest coast of India. J Mar Biol Assoc 1(1): 33-49.

17. Darbyshire M (1967) The surface waters off the coast of Kerala, southwest India. Deep Sea Res 14: 295-320.

18. Johannessen OM, Subbaraju G, Blindheim J (1981) Seasonal variations of the oceanographic conditions off the southwest coast of India during 1979-1975. Fiskeridirektorates Skrifter, Serie Havundersoekelser 18: 247-261.

19. Maheswaran M (2000) Upwelling along the southwest coast of India. Ind J Mar Sci 15: 20-24.

20. Muni Krishna K (2007) A Study of Coastal Upwelling Phenomena along the Indian Coasts Using Satellite Observations and Model Simulations. Ph.D thesis, Andhra University, Visakhapatnam, India.

21. Muni Krishna K, Ramalingeswara Rao S (2008) Seasonal and interannual variability of sea surface chlorophyll a concentration in the Arabian Sea. Journal of Applied Remote Sensing 2(1): 1-12.

22. Slutz R, Lubker SJ, Hiscox JD, Woodruff SD, Jenne RL, et al. (1985) Comprehensive Ocean-Atmosphere Data Set; Release 1, 268 pp., NOAA Environ Res Lab, Clim Res Program, Boulder, Colorado, USA.

23. Woodruff SD, Slutz RL, Jenne RL, Steurer PM (1987) A Comprehensive ocean-atmosphere data-set. Bull Am Meteorol Soc 68: 1239-1250.

24. Woodruff SD, Diaz HF, Elms JD, Worley SJ (1998) COADS released 2 data and metadata enhancement for improvements of marine surface flux fields. Phys Chem Earth 23: 517-526.

25. Worely SJ, Woodruff SD, Reynolds RW, Lubker SJ, Lott N (2005) ICOADS Release 2.1 data and products. Int J Climatol (CLIMAR-II Special Issue), 25(7): 823-842.

26. Mantua NJ, Hare SR, Zhang Y, Wallace JM, Francis RC (1997) A Pacific decadal climate oscillation with impacts on salmon. Bulletin of the American Meteorological Society 78: 1069-1079.

27. Xie L, Hsieh WW (1991) Upwelling winds along the west coast of North America, 1899-1988. Dep Oceanogr Manuscr Rep No. 58, University of British Columbia, Vancouver, BB, Canada.

28. Ware DM (1995) A century and a half change in the climate of the NE Pacific. Fish Oceanogr 4(4): 267-277.

\section{Your next submission with Juniper Publishers will reach you the below assets}

- Quality Editorial service

- Swift Peer Review

- Reprints availability

- E-prints Service

- Manuscript Podcast for convenient understanding

- Global attainment for your research

- Manuscript accessibility in different formats ( Pdf, E-pub, Full Text, Audio)

- Unceasing customer service

Track the below URL for one-step submission https://juniperpublishers.com/online-submission.php 